\title{
Smoking under hypoxic conditions: a potent environmental risk factor for inflammatory and autoimmune diseases
}

Md. Saddam Hussain and Vishwas Tripathi*

\begin{abstract}
Autoimmune disease management presents a significant challenge to medical science. Environmental factors potentially increase the risk of developing inflammatory and autoimmune diseases, such as multiple sclerosis, rheumatoid arthritis, and lupus. Among various environmental stresses, cigarette smoke and hypoxia have both been reported to lead to an enhanced risk of inflammatory and autoimmune diseases.

In this review, we shed light on all reported mechanisms whereby cigarette smoke and a hypoxic environment can induce inflammatory and autoimmune diseases and discuss how hypoxic conditions influence the cigarette smokeinduced threat of inflammatory and autoimmune disease development.

Cigarette smoke and hypoxia both lead to increased oxidative stress and production of reactive oxygen species and other free radicals, which have various effects including the generation of autoreactive pro-inflammatory $T$ cells and autoantibodies, reductions in T regulatory $\left(T_{\text {reg }}\right)$ cell activity, and enhanced expression of pro-inflammatory mediators [e.g., interleukin-6 (IL-6), interleukin-4 (IL-4) and interleukin-8 (IL-8)]. Accordingly, smoking and hypoxic environments may synergistically act as potent environmental risk factors for inflammatory and autoimmune diseases. To our knowledge, no studies have reported the direct association of cigarette smoke and hypoxic environments with the risk of developing inflammatory and autoimmune diseases.

Future studies exploring the risk of autoimmune disease development in smokers at high altitudes, particularly military personnel and mountaineers who are not acclimatized to high-altitude regions, are required to obtain a better understanding of disease risk as well as its management.
\end{abstract}

Keywords: Inflammatory and autoimmune diseases, Cigarette smoke, Hypobaric hypoxia, Oxidative stress, Epigenetic modifications, Pro-inflammatory mediators, Autoantibody

\section{Background}

Autoimmune disease has been a hot topic in medical science for the last decade. Autoimmunity is the state of the immune system in which immune cells recognize self-molecules as antigens and become hyperactive to eliminate these molecules, resulting in chronic inflammation, pain and various other severe conditions. Currently, a major portion of the world population [1] suffers from various types of autoimmune diseases, including rheumatoid arthritis (RA), systemic lupus erythematosus (SLE), multiple sclerosis (MS), thyroid disease, inflammatory bowel disease (IBD), Graves' disease (GD), and Behcet's syndrome. The major challenges of autoimmune diseases are to decipher their precise causes and mechanisms to develop more effective and efficient treatments.

Environmental factors play crucial roles in the development and progression of inflammatory and autoimmune diseases. Among such factors, cigarette smoke (CS) and hypoxia are two potent environmental stresses that can significantly cause imbalance in normal immune homeostasis by modulating immune-regulatory activities, which may lead to inflammatory and autoimmune diseases.

* Correspondence: drvishwastripathi@gmail.com; vishwas@gbu.ac.in 
Despite widespread knowledge of the health risks posed by tobacco consumption in the form of smoke and other means, consumption of tobacco remains unacceptably prevalent [2]. Tobacco smoking killed almost 6 million people worldwide in 2011, which include about 600,000 people that never smoke and died due to indirect second-hand smoke. If it follows the same way, the death number will reach to 800,000 per year by 2030 , higher than the mortality resulting from human immunodeficiency virus and acquired immune deficiency syndrome (HIV/AIDS), tuberculosis and malaria combined. Indeed, the threat of tobacco smoking to public health can be considered to be a worldwide epidemic [3-7]. CS can lead to inflammatory and autoimmune diseases through multiple mechanisms, including the following: genetic/epigenetic modifications; increased oxidative stress, reactive oxygen species (ROS), and free radical production, and nicotine and heavy metal toxicity. These effects, in turn, may increase $\mathrm{B}$ and $\mathrm{T}$ cell proliferation, reduce immune suppressive $\mathrm{T}$ regulatory (Treg) cell proliferation and activity as well as autoantibody generation, and enhance expression of proinflammatory mediators, such as IL-6, IL-8, tumor necrosis factors (TNFs) and Interferon gamma (INF- $\gamma$ ). Hence, CS is a risk factor for developing inflammatory and autoimmune diseases.

Decreased oxygen availability (hypobaric hypoxia at high altitude or cellular hypoxia) can also alter the normal function of the immune system in multiple ways, making it to be more susceptible to various inflammatory and autoimmune diseases. Recent advancements in our understanding of oxygen-dependent cell signaling have revealed several mechanisms by which hypoxia impacts the development of inflammation through the coordinated expression of inflammatory, adaptive and apoptotic genes. Hypoxia is a distinctive microenvironmental feature in a number of inflammatory conditions, including IBD and arthritis [8-10]. Hypoxia induces increased expression of hypoxia-inducible factor (HIF), resulting in overexpression of pro-inflammatory mediators, and also causes enhanced oxidative stress, which results in autoantibody generation and transformation of $\mathrm{CD}_{4}^{+} \mathrm{T}$ cells into auto-reactive pro-inflammatory cells.

In this review, we highlight the effects of smoking and hypoxic conditions (hypobaric hypoxia and cellular hypoxia) on the immune system and focus on different ways by which these conditions increase the risk of developing inflammatory and autoimmune diseases. To our knowledge, the combined effect of smoking and hypoxia on the immune system and the subsequent risk of developing autoimmune diseases have not yet been reviewed. Therefore, we summarize all available information concerning the association of smoking and hypoxia with the risk of developing various inflammatory autoimmune diseases. Based on the findings, we propose that the combination of smoking and hypoxic conditions may act as a potent environmental risk factor for inflammatory and autoimmune disease development. Future studies are needed to explore the risk of the development of autoimmune diseases in smokers in high-altitude regions, specifically military personnel and mountaineers who are not acclimatized to high-altitude stresses. These findings may also help to enhance our current understanding and management of human health in highaltitude regions.

\section{CS and autoimmune diseases: overview}

Tobacco consumption, either in the form of CS or other means, is theoretically an avoidable environmental factor yet a major cause of various health issues and death worldwide [5-7]. CS contains thousands of complex, dynamic, and reactive chemical constituents that possess cytotoxic, mutagenic, immune-modulators and tumorigenic properties [11-23]. Several toxic components of CS have immunomodulatory effects that result from genetic/epigenetic changes and lead to altered gene expression and function; some examples include changes in pro-inflammatory cytokine expression and histone deacetylase (HDAC) and histone acetylase (HAT) activities [2]. Several studies have demonstrated CS to be a potent environmental risk factor for certain autoimmune diseases, such as RA, MS, and SLE [24-26]. Since the first evidence provided in 1987 by Vessey and colleagues [27] that CS increases the risk of RA development (approximately 2.4 times elevated risk among women smokers) until 2006, 11 case-control and 4 cohort studies have been reported, showing an increased risk of RA development in cigarette smokers (Table 1) [24, 26-40]. In fact, a twofold increased risk of developing seropositive RA for individuals who smoked for more than 20 years and a threefold increased risk for RA in male smokers have been reported [2, 41-43]. In addition, Freemer and coworkers conducted a case-control study showing a link between CS and SLE; these authors reported the presence of an increased level of anti-dsDNA antibodies in current smokers compared to former-and non-smokers with SLE (Table 1) [42]. Furthermore, the association of CS with an increased risk of MS is also evident based on the results of various epidemiological studies [44-48] (Table 1, [24-68]).

\section{CS and associated genetic changes}

Somatic mutations are reported to be crucial factors in the pathogenesis of autoimmunity. To induce autoimmunity, coherent type-a somatic mutations are required, which occur in multiple cells to such an extent that somatically mutated proteins lose their normal functions and/or are interpreted by the immune system 
Table 1 Reported epidemiological studies of the relationship between CS and the risk of selected autoimmune diseases

\begin{tabular}{|c|c|c|c|}
\hline $\begin{array}{l}\text { Autoimmune } \\
\text { disease }\end{array}$ & $\begin{array}{l}\text { Case-control studies } \\
\text { (No. of studies showing } \\
\text { increased risk/total no. } \\
\text { of studies) }\end{array}$ & $\begin{array}{l}\text { Cohort studies } \\
\text { (No. of studies showing } \\
\text { increased risk/total no. } \\
\text { of studies) }\end{array}$ & Range of observed $O R(R R)$ of developing diseases \\
\hline RA & $11 / 12[24,26-28,31-34,36-39]$ & $4 / 4[29,30,35,40]$ & $\begin{array}{l}0.6-3.4 \\
\text {-Risk increases with increases in the duration } \\
\text { and intensity of smoking } \\
\text {-Males are more prone }\end{array}$ \\
\hline MS & $1 / 3[44-46]$ & $2 / 2[47,48]$ & $\begin{array}{l}\text { 1.6-1.9 } \\
\text {-Risk increases with increases in the intensity } \\
\text { of smoking }\end{array}$ \\
\hline SLE & $3 / 8[49-56]$ & $0 / 2[57,58]$ & $\begin{array}{l}0.5-6.7 \\
\text {-Current smokers are mainly at risk }\end{array}$ \\
\hline GD & $8 / 8[42,59-65]$ & $1 / 1[66]$ & $\begin{array}{l}1.3-8.2 \\
\text {-Current smokers are at higher risk than former } \\
\text { smokers } \\
\text {-Risk increases with increases in the intensity of } \\
\text { smoking } \\
\text {-Females might be more prone }\end{array}$ \\
\hline Primary biliary cirrhosis & $2 / 2[67,68]$ & - & $1.6-3.5$ \\
\hline
\end{tabular}

RA Rheumatoid arthritis, MS Multiple sclerosis, SLE Systemic lupus erythematosus, GD Graves' disease, - No data

to be non-self, i.e., autoantigens [69]. Simple tandem repeats (STRs) within protein coding genes, including microsatellites and mini-satellites are highly vulnerable regions that are susceptible to mutations in somatic and germ-line cells, and somatic mutations in these STRs generate novel, highly immunogenic proteins $[70,71]$ that may induce autoimmunity. Moreover, repetitive sequences play a crucial role in methylating nearby sequences [72]. Indeed, mutations in repeat sequences often result in significant changes in methylation patterns [73], which in turn alter normal splicing [74], and altered methylation has been associated with several autoimmune diseases [75]. Overall, the mutability of tandem repeats intensifies with increasing repeat length, repeat count, and high repeat identity [76]. Long STRs within 20 genes have been associated with 16 common autoimmune diseases; these genes include the following: thyroid peroxidase (TPO), which encodes a primary autoantigen in Hashimoto's thyroiditis (HT) and Grave's disease (GD); filaggrin (FLG), which encodes a primary autoantigen in RA; and protein-tyrosine phosphatase, receptor-type, $\mathrm{n}$, polypeptide 2 (PTPRN2), which encodes a primary autoantigen in type-1 diabetes (T1D) (see Table 7 of reference [76]). Single-nucleotide polymorphisms (SNPs) are also associated with the pathogenesis of autoimmune diseases. The functional SNP rs2476601 in the PTPN22 gene has been linked to many autoimmune diseases, though no association has been found for MS, pernicious anemia (PA), and Sjogren's syndrome (SJ) (see Table 1 of reference [76]). This SNP specifically affects $\mathrm{T}$ cell signaling [77, 78], B cell signaling [79, 80]; causes autoreactive B cell generation [79], and T cell and dendritic cell hyper-responsiveness [81].
Exposure to CS, directly (mainstream tobacco smoke; MTS) or indirectly (second-hand smoking), is mutagenic, and MTS is considered to be the most extreme example of a human systemic mutagen [82]. CS contains more than 4,000 chemical constituents [83], many of which are genotoxic and interact with DNA to induce mutations and gene activation, leading to the development of autoimmune diseases [82, 84]. Somatic mutations result in autoimmunity, and CS induces both somatic and germline mutations [82, 85]. Evidence of CS-induced somatic mutations is well reported [82, 86, 87]. For example, the frequency of somatic hypoxanthine-guanine phosphoribosyl transferase (HPRT) gene mutations is significantly elevated in both adult smokers [88] and newborns of smoking mothers [89]. CS has also been specifically associated with the production of autoantibodies against primary autoantigens encoded by mutated enolase [90], vimentin [91], and fibrinogen beta [91] genes in RA. Although elevated levels of DNA adducts, strand breaks and oxidative damage have been reported in the sperm of male smokers [82, 92], evidence for MTS-induced heritable germ-line mutations is lacking. In 2007, Yauk et al. [93] reported that MTS induces a significantly elevated frequency of germline mutations at the expanded simple tandem repeat (ESTR) locus $M s 6-h m$ in mouse sperm, which could, at least theoretically, be inherited in subsequent generations.

\section{Epigenetic modifications induced by CS}

All known epigenetic pathways are altered by both active and passive (including in utero) $\mathrm{CS}$ and such epigenetic changes can be transmitted to the next generation through the male germ line [94]. Such epigenetic 
alterations caused by CS include post-translational modifications through HAT, HDAC, and DNA methyl transferase (DNMT), leading to chromatin remodeling and changes in gene expression [95].

\section{Histone acetylation/deacetylation}

Reversible acetylation/deacetylation of conserved lysine residues (at $\alpha$-amino groups) in the histone tails of chromatin has an important function in regulating gene transcription [96]. Acetylation of histones promotes gene expression by facilitating the recruitment of transcription factors, such as NF- $\mathrm{kB}$, and enabling access of the transcriptional machinery to DNA. Conversely, deacetylation of histones negatively regulates transcription by decondensing the chromosome and decreasing the accessibility of transcription factors, including NF- $\mathrm{kB}$ and $\mathrm{AP}-1$, to their respective DNA binding motifs $[95,97-99]$.

HAT and HDAC are responsible for acetylating and deacetylating, respectively, lysine residues on histone and nonhistone proteins. To date, 18 isoforms of HDAC have been identified in humans named as HDAC-1 to HDAC-11 and SIRT-1 to SIRT-7 which are further classified into four major groups namely class 1 to class 4 [100-103]. The addition of acetyl groups to histone lysine residues by HATs cause unwinding of chromatin and hence transcriptional activation of genes. In contrast, HDACs function as transcriptional co-repressors by removing acetyl groups, which results in chromosomal condensation, exclusion of transcription factors and, eventually, inhibition of gene transcription. In addition to histones, HDACs also deacetylate non-histone proteins, such as NF- $\mathrm{kB}$, and regulate NF-kBdependent pro-inflammatory gene transcription $[95,102]$. Indeed, HATs and HDACs play significant roles in the immunological balance, and alterations in the functions of these proteins lead to immunological disorders. Furthermore, HDAC-1, -3, -6, -9 and SIRT-1 also act as inhibitors of $\mathrm{T}_{\text {reg }}$ cell development and inhibit their immunesuppressive function by deacetylating FOXP3 (a bona fide marker of active $\mathrm{T}_{\text {reg }}$ cells), whereas HATs [p300, TIP60, and PCAF (p300/CREB binding protein-associated factor)] acetylate FOXP3 and positively regulate $\mathrm{T}_{\text {reg }}$ cell development and function $[104,105]$. As $T_{\text {reg }}$ cells negatively regulate autoimmune processes, inhibition of $\mathrm{T}_{\text {reg }}$ cell function and development as a result of enhanced HDAC function and/or HAT inhibition potentially lead to inflammatory and autoimmune diseases.

CS causes imbalance in the normal histone acetylation/deacetylation process, leading to sustained transcription of pro-inflammatory protein genes by inhibiting HDAC activity and activating NF- $\mathrm{kB}$ and AP1, which in turn results in chronic inflammation (Fig. 1a) [106]. Moreover, CS stimulates oxidative stress by inducing generation of ROS, $\mathrm{H}_{2} \mathrm{O}_{2}$ and free radicals. HDAC2 activity is significantly reduced in response to smokinginduced oxidative stress, and alteration of HDACs by CS exposure leads to histone acetylation and SIRT1 posttranscriptional modifications and subsequent degradation; this disrupts the co-repressor complex (SIRT1RelA/p65 complex) and leads to activation of redoxsensitive transcription factors such as NF- $\mathrm{kB}$, increasing transcription of pro-inflammatory genes encoding IL-8, IL-6, and TNFs [2, 96, 106-114].

HDAC inhibition and HAT activation through cigarette smoke constituents (CSCs) and the increased oxidative stress induced by CS result in higher Nrf2 acetylation, which destabilizes the protein. These effects reduce anti-oxidant gene expression and increase sensitivity to oxidative stress, making individuals more prone to chronic obstructive pulmonary disease (COPD)-like inflammatory and autoimmune diseases $[96,115]$.

\section{DNA methylation/demethylation}

DNA methylation, an important heritable epigenetic change that occurs at cytosine residues in CpG motifs, stabilizes chromatin in a tightly packed conformation, thereby suppressing gene expression [108]. DNA methylation and demethylation are catalyzed by a specific group of enzymes, DNMTs and DNA methylases, respectively. These enzymes are sensitive to environmental factors; for example, oxidative stress due to cigarette smoking can result in reduced DNMT-1 activity and thus increased DNA demethylation [116].

Studies have shown that CSCs and ROS/reactive nitrogen species (RNS), e.g., $\mathrm{H}_{2} \mathrm{O}_{2} / \mathrm{NO}_{3}$, inhibit the extracellular signal-regulated kinase (ERK) signaling pathway in T cells, leading to a reduction in DNMT-1 expression and thus reduced DNA methylation. This effect, in turn, results in chromatin remodeling, leading to increased expression of methylation-regulated genes (Fig. 1b) that contribute to lupus flare-like autoimmune disease. DNMT-1 inhibition due to CS-induced oxidative stress increases expression of lymphocyte functionassociated antigen-a heterodimer composed of CD11a and CD18 [LFA (CD11a/CD18)] and CD70 in T cells and changes antigen-specific $\mathrm{CD} 4^{+} \mathrm{T}$ helper cells into auto-reactive pro-inflammatory cells, which respond to self-class 2 MHC molecules without added antigens and kill autologous macrophages, resulting in lupuslike autoimmunity $[108,116]$.

\section{Histone phosphorylation}

Although information regarding phosphorylation of histones is limited, it is clear that these molecules play significant roles in chromatin conformation and thereby regulate gene transcription. Studies have shown that phosphorylation of histone $\mathrm{H} 3$ facilitates its acetylation, which involves cAMP-response element-binding protein 


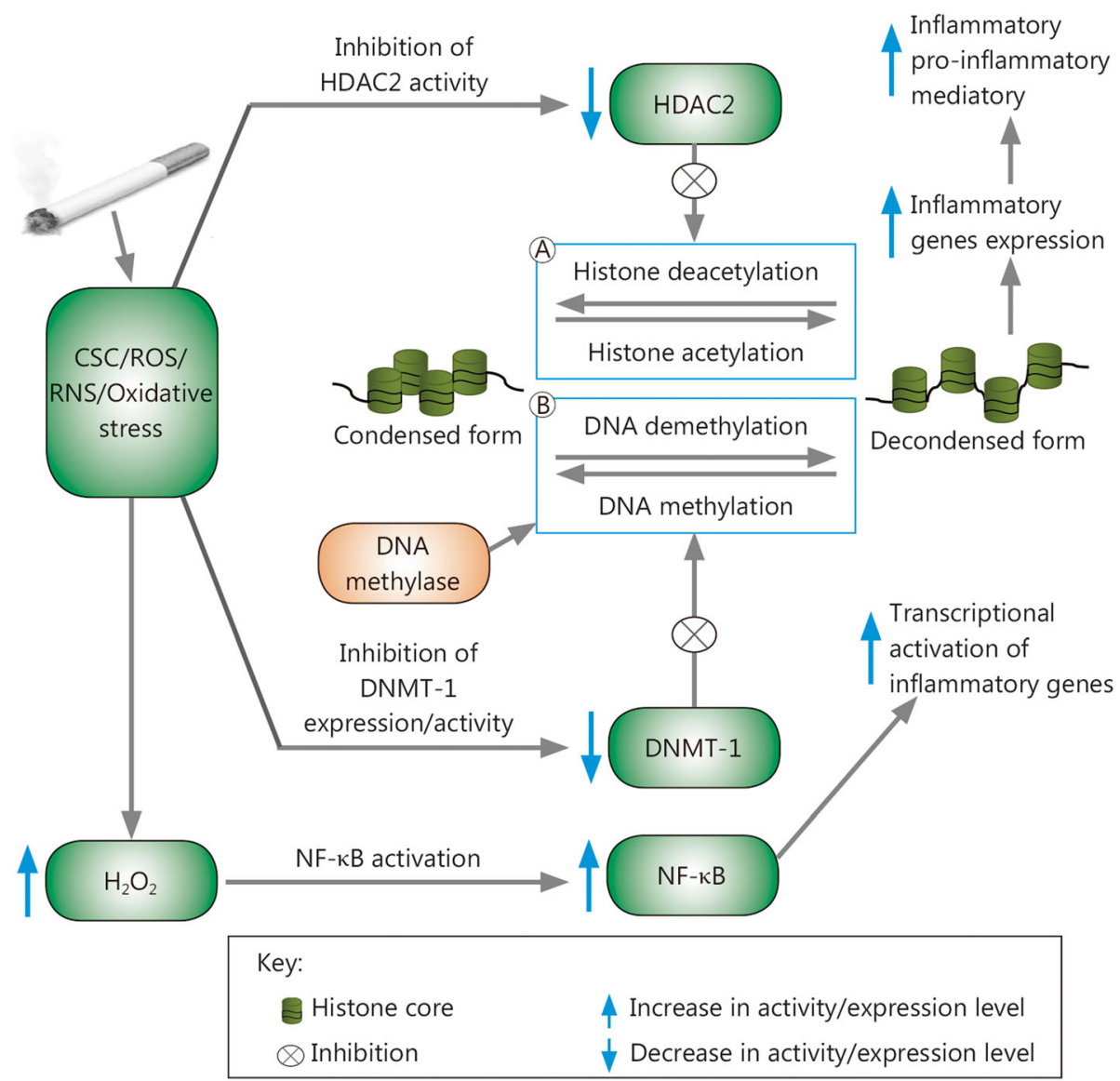

Fig. 1 Epigenetic modifications induced by cigarette smoke. a Acetylation: via a decrease in HDAC2 activity and NF-kB activation, cigarette smoke induces an increase in histone-4 acetylation and hence up-regulation of inflammatory gene expression. $\mathbf{b}$ DNA methylation: in mammals, the cytosine in CpG motifs (not shown in the figure) can be reversibly methylated at the 5' position by DNMT; CSC and ROS/RNS produced in cigarette smoke reduce DNMT-1 expression/activity, inhibiting DNA methylation and hence enhancing expression of methylation-regulated inflammatory genes, which leads to inflammatory and autoimmune diseases. CSCs. cigarette smoke constituents; DNMT. DNA methyl transferase; HDAC2. histone deacetylase-2; NF-kB. nuclear factor-kappa B; ROSs. reactive oxygen species; RNS. reactive nitrogen species

(CREB-binding protein) [117]. Cigarette smoke results in increased levels of phosphorylated (Ser10) and acetylated (Lys 9) histone $\mathrm{H} 3$, which leads to increased proinflammatory cytokine release by macrophages and mouse lungs [118]; these events indicate a potential risk of inflammatory and autoimmune diseases.

\section{CS and autoantibody production}

Many studies have reported an association between CS and the production of autoantibodies, such as anticitrullinated peptide antibodies and autoantibodies against elastin [2]. Increased sero-positivity for dsDNA (i.e., anti-dsDNA antibodies) has been found in current smokers relative to former smokers and serves as a diagnostic marker for SLE [42, 119]. A lack of methylation or demethylation leads to anti-dsDNA antibody production, which sufficiently induces lupus-like autoimmunity in genetically predisposed mice and, likely, humans [108]. Oxidative stress caused by CS is a potential risk factor for autoantibody production. For example, elevated ROS in red blood cells (RBCs) results in the production of autoantibodies against RBCs and causes autoimmune hemolytic anemia (AIHA) [117].

\section{CS and heavy metals}

The filler tobacco used in cigarettes of different brands contains $\mathrm{Cd}$ (Cadmium), $\mathrm{Ni}$ (Nickel) and $\mathrm{Pb}$ (Lead) at concentrations that range 1.73-2.02, 0.7151.52 , and $0.378-1.16 \mu \mathrm{g}$ per cigarette, respectively, and this increased exposure of toxic metals due to CS may increase RA risk [43]. For instance, oral exposure to $\mathrm{Cd}$ at environmental levels has been associated with the increased production of autoantibodies, which may be due to dose-sensitivity and polyclonal $B$ cell activation (PBA) [120], and Pb exposure via CS increases the risk of MS [121].

$\mathrm{Ni}$ and $\mathrm{Cd}$ strongly activate NF- $\mathrm{kB}$ and induce the release of IL- 8 in the THP-1 human monocytic leukemia 
cell line. Cadmium also induces TNF- $\alpha$ and IL-6 release in THP-1 monocytic cells. Hence, sustained activation of transcription factors (e.g., NF-kB) by metal-activated signaling may lead to chronic inflammatory processes and related diseases, such as autoimmune disorders [122]. Moreover, nicotine has been associated with autoimmune arthritis and may also differentially affect the severity of rodent autoimmune arthritis [2].

\section{CS and altered function of immune system}

The reported potential mechanisms by which CS promotes RA include augmentation of autoreactive B cells functions [38], altered antigen presentation by the CS-impaired antigen presentasome (APS) [123, 124], changes in $T_{\text {reg }}$ cell functions (also promoting COPD) [125] and activation and proliferation of $\mathrm{T}$ cells by antigens present in CS. Furthermore, CS significantly reduces the cytotoxic activity of natural killer (NK) cells [126], which destroy auto-reactive $\mathrm{T}$ cells that promote autoimmune disease [127], and reduces the production of IFN- $\gamma$ and TNF- $\alpha$ by activated NK cells [126]. Another study reported that CS also induces polyclonal activation of both $\mathrm{B}$ and $\mathrm{T}$ cells, enhances the production of several cytokines (e.g., IL-2, IL-4, and soluble ICAM-1) while reducing that of IFN- $\gamma$, increases serum IgE levels, and enhances antigen presentation by damaging cells. This evidence suggests a potential link between CS and the development and an increased risk for inflammatory and autoimmune diseases, including RA, Good pasture syndrome, Grave's ophthalmopathy and autoimmune hypothyroidism [128].

$\mathrm{T}$ cells may be induced to proliferate into different types of inflammatory cells, categorized as Th1, Th2, and Th17 type inflammation-inducing and respective pro-inflammatory cytokine-producing $\mathrm{T}$ cells [129]. Compared to non-smokers, smokers have enhanced IL13 (Th2 cytokine) levels and reduced levels of Th-1 cytokines; hence, CS may be considered to be an environmental agent that induces Th2 type inflammation or acts as an adjuvant of adaptive Th2 immunity [124, 130-134]. Available evidence also suggests that in certain individuals, chronic CS exposure causes Th17 inflammationassociated inflammatory diseases and may also promote adaptive Th17 immunity to self-antigens $[24,135,136]$. Moreover, CS-induced oxidative stress increases expression of LFA (CD11a/CD18) and CD70 in T cells and changes antigen-specific $\mathrm{CD} 4^{+} \mathrm{T}$ helper cells into autoreactive pro-inflammatory cells, which respond to self-class 2 major histocompatibility complex (MHC) molecules without added antigens and kill autologous macrophages, potentially causing lupus-like autoimmunity $[108,116]$.

\section{Hypoxic conditions and inflammatory disorders}

Environmental conditions potentially challenge the capacity of the human body's defense network. Hypoxia associated with high altitude, which is typically regarded as an elevation over $2,400 \mathrm{~m}$, is an important environmental assault. For example, if the $\mathrm{O}_{2}$ concentration at sea level is accepted to be $100 \%$, this percentage gradually decreases with increasing elevation. Thus, the decreased $\mathrm{O}_{2}$ availability at high altitude, i.e., hypobaric hypoxia, due to reduced $\mathrm{O}_{2}$ pressure results in increased formation of ROS and RNS (RONS), a process that is linearly related to the elevation, degree of hypoxia and duration of exposure. In these cases, the ROS levels exceed the defense response of the body, which in turn enhances oxidative damage to macromolecules such as lipids, proteins, and DNA as well as the entire cell (Fig. 2). Exposure to hypobaric hypoxia also significantly reduces the activity and effectiveness of both enzymatic and nonenzymatic antioxidant systems. Moreover, during highaltitude exposure, different RONS-producing sources, including the mitochondrial electron transport chain, xanthine oxidase, and nitric oxide synthase (NOS), gets activated; UV radiation is also strongly increased, leading to overproduction of ROS [137-140]. Elevated ROS levels may lead to or increase the risk for inflammatory and autoimmune diseases through heightened autoantibody production, including anti-dsDNA antibodies, and pro-inflammatory gene expression, and the generation of auto-reactive T cells.

Among the various transcription factors that facilitate cellular adaptation to hypoxic environments (e.g., hypobaric hypoxia or cellular hypoxia), HIF-1 is one of the most important. HIF-1 was first reported in a nuclear extract of the Hep3B human hepatoma cell line [141] and subsequently described as a heterodimeric protein comprising HIF- $1 \alpha$ and $-1 \beta$ subunits. The $\beta$ subunit is constitutively expressed, whereas $\alpha$ subunit is stabilized in the absence of oxygen. There are three isoforms of $\alpha$ subunit, HIF- $1 \alpha$, HIF- $2 \alpha$ and HIF-3 $\alpha$, which are distinguished by the presence of basic helix-loop-helix (bHLH), Per-ARNT-Sim (PAS) and oxygen-dependent degradation (ODD) domains. Despite the many structural and functional similarities, HIF- $1 \alpha$ is ubiquitously expressed, whereas HIF- $2 \alpha$ is tissue specific and, in certain cases mediates different biological functions [142]. HIF- $2 \alpha$ isoforms have also been implicated in cartilage destruction: in an arthritis mouse model, HIF- $2 \alpha$ induced chemokine expression in chondrocytes, which stimulated the migration and invasion of synovial fibroblasts, leading to cartilage erosion [143]. Recent studies have shown that HIF- $2 \alpha$ plays a fundamental role in RA, independent of HIF-1 $\alpha$. Under hypoxic conditions, HIF$1 \alpha$ expression is enhanced via inactivation or reduced activity of prolyl hydroxylase (PHD) enzymes, which 


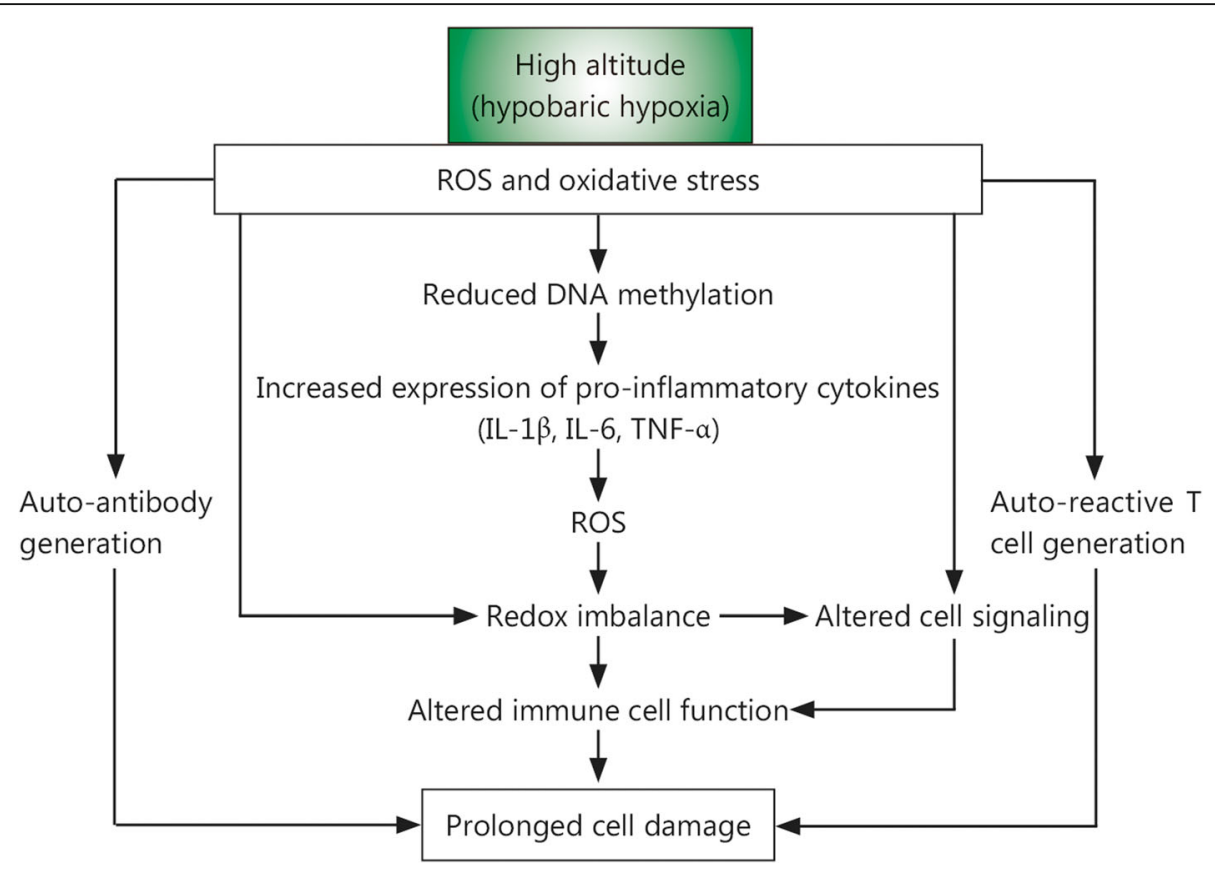

Fig. 2 Potential mechanisms of hypobaric hypoxia-induced inflammation. Hypobaric hypoxia enhances the ROS level in body beyond the limit of tolerance, which further induces oxidative damage and alters the immune cell functions. The increased oxidative stress in turn heightens the expression of pro-inflammatory cytokines, generation of autoantibodies (e.g., anti-dsDNA, anti-elastin and anti-RBC autoantibodies) and conversion of T helper cells into auto-reactive T cells, eventually results in persistence inflammation and prolonged cell damage. ROS, Reactive oxygen species; IL, Interleukin

degrade and destabilize HIF-1 $\alpha$ under normoxic conditions through oxidation of the ferrous ion at the active site $[144,145]$. Under normoxic conditions, PHD catalyzes hydroxylation of proline residues in the ODD domains of HIF-1 $\alpha$. The tumor suppressor von Hippel Lindau (vHL) protein subsequently recognizes these hydroxylated residues and recruits the ubiquitin ligase complex, leading to poly-ubiquitination and eventual proteasomal degradation of HIF-1 $\alpha$ [146]. Asparagyl $\beta$ hydoxylases, also called factor-inhibiting HIF-1 (FIH-1), can also suppress HIF- $1 \alpha$ activity by hydroxylating asparagine residues in the $\mathrm{C}$-terminal trans-activation domain, thereby preventing HIF- $1 \alpha$ interaction with its coactivator [147-149]. As these oxygen-dependent modifications do not occur under hypoxia, HIF- $1 \alpha$ does not bind to vHL, resulting in stabilization and accumulation of HIF- $1 \alpha$ in the cytoplasm, followed by its translocation to the nucleus. Inside the nucleus, HIF- $1 \alpha$ dimerizes with the HIF-1 $1 \beta$ subunit, forming the HIF- $1 \alpha \beta$ heterodimer that binds to the promoter region of HIF-regulated genes [150]. Cramer et al. [8] reported the first evidence of the involvement of HIF- $1 \alpha$ in the inflammatory process, showing that HIF- $1 \alpha$ deletion in macrophages reduces the severity of disease in different models of acute and chronic inflammation, including a passively induced arthritis disease model. HIF- $1 \alpha$ also promotes signaling pathway activation and regulates IL-33 production by fibroblasts, which in turn induces expression of HIF- $1 \alpha$ and forms a regulatory mechanism that perpetuates inflammation in RA [151]. Loss or inhibition of HIF- $1 \alpha$ function enhances $\mathrm{T}_{\text {reg }}$ cell differentiation and function $[150,152]$. Thus, hypoxic conditions that increase the synthesis of the HIF- $1 \alpha$ protein, a negative regulator of FOXP3 (a bona fide marker of $\mathrm{T}_{\text {reg }}$ cell) expression, significantly reduce the development and activity of $\mathrm{T}_{\text {reg }}$ cells, thereby increasing the risk of inflammatory and autoimmune diseases.

HIF- $1 \alpha$ is inhibited by HDAC [153], and smoking, as noted above, is an inhibitor of HDAC [2]. Thus, smoking under hypoxic conditions leads to increased HIF- $1 \alpha$ activity, which in turn reduces the proliferation and activity of $T_{\text {reg }}$ cells. Hence, smoking in a hypoxic state is a potent risk factor for various inflammatory and autoimmune diseases. Hypoxia-induced HIF- $1 \alpha$ expression increases the maturation of dendritic cells, which results in inflammatory immune responses, e.g., renal injury [154].

Furthermore, HIF-1 regulates the Th17/ $\mathrm{T}_{\text {reg }}$ balance, and studies have shown that the imbalance between the number and function of Th17 and $\mathrm{T}_{\text {reg }}$ cells may lead to inflammatory and autoimmune diseases, such as IBD and RA, and impact their severity. During hypoxia, HIF1 promotes Th17 differentiation, prevents apoptosis and inhibits $\mathrm{T}_{\text {reg }}$ cell differentiation; down-regulation and/or 
dysfunction of $\mathrm{T}_{\text {reg }}$ cells promote autoimmune diseases and inflammation [155].

In addition to HIF, the key cellular response to hypoxia, nearly 20 different transcriptional factors that directly or indirectly sense hypoxic microenvironments have been identified [156]. The principle factors are members of the NF- $\kappa B$ family, the activation of which has been extensively reported in many cell types in response to hypoxia [156, 157], which are also the main pro-inflammatory transcription factors. Individuals exposed to hypobaric hypoxia show increased activation of NF-kB. Under normoxic conditions, PHDs hydroxylate and inhibit IKK activity, which does not occur under hypoxic conditions, enabling IKK-mediated phosphorylation and promoting degradation of IKB and thus activating NF- $\kappa B$. NF- $\kappa B$ further activates expression of various pro-inflammatory cytokines, chemokines, TNF$\alpha$, IL-6, IL-8, vascular endothelial growth factor (VEGF), matrix metalloproteinase (MMP) $1,-3$, and -13 , and many other proteins that lead to the activation of a positive feedback loop, which enhances activation of more pro-inflammatory signals and eventually results in chronic and persistent inflammation, tissue destruction [158-161] and autoimmune diseases. Abnormal activation of NF- $\mathrm{BB}$ has been associated with inflammationrelated diseases, particularly RA and IBD [162]. Moreover, hypoxia is a characteristic of RA synovial tissue [163-166], and NF-kB is overexpressed in this tissue [159]. In RA, hypoxia might play a role in sustaining and inducing inflammation, consistent with the study of Jeon and colleagues [167], who used a murine model of collagen-induced arthritis (CIA). Synovial fibroblasts in RA patients express an endogenous TLR ligand called high-mobility group box 1 (HMGB-1), which upregulates expression of VEGF, thereby exacerbating RA [168], though inhibition of HIF- $1 \alpha$ leads to attenuation of the HMGB-1 protein. Hypoxia and IL-17 increase expression of MMP2 and MMP9 via the NF-kB-HIF- $1 \alpha$ pathway and thus synergistically promote the migration and invasion of synovial fibroblasts in RA [169]. RA synovial fibroblasts exposed to hypoxia have increased levels of MMPs (MMP1 and MMP3) and decreased levels of tissue inhibitors of MMP1 (TIMP-1) at both the mRNA and protein levels, promoting the destruction of articular cartilage in these patients $[170,171]$. The hypoxiainducible transcription factor Ets-1 [172] has also been implicated in the invasion and destruction of cartilage and bone in RA [173].

In addition to acting independently in the regulation of gene expression in hypoxic inflammation, HIF and NF- $\mathrm{KB}$ also exhibit a significant level of crosstalk. NF- $k B$ plays an important role in the up-regulation of HIF- $1 \alpha$ mRNA expression [174-176], and HIF-1 $\alpha$ can also modulate NF-kB signaling. A previous study showed that mice overexpressing
HIF- $1 \alpha$ in keratinocytes had increased activity and expression of NF- $\mathrm{kB}$, which regulates pro-inflammatory and antiapoptotic genes, resulting in hyper-responsiveness to inflammatory stimuli [177].

However, it remains unclear whether HIF- $1 \alpha$ acts as an inflammatory or anti-inflammatory factor. As HIF- $1 \alpha$ promotes the survival of inflammatory cells [8], it can be considered to be pro-inflammatory. In contrast, expression of HIF- $1 \alpha$ in intestinal epithelial cells contributes to an intestinal epithelial barrier function in cases of inflammation, and the intestinal epithelial barrier prevents non-specific movement of luminal antigenic substances into the subepithelial lamina propria. Thus, in this context, the HIF pathway can be considered anti-inflammatory [178]. A previous study reported that overexpression of HIF- $2 \alpha$ increased inflammation and RA, whereas overexpression of HIF- $1 \alpha$ did not [145]. NF- $\mathrm{KB}$ activation under hypoxic conditions stabilizes HIF- $1 \alpha$, thereby activating the HIF-1 transcription factor. Another study showed that prolonged HIF activation in healthy individuals living at high altitudes might reduce NF- $\mathrm{KB}$ activity, effectively dampening immune responses [145]. Thus, the role of NF- $k B$ in hypoxia-induced inflammatory and autoimmune diseases requires further investigation.

A glycolytic shift is another mechanism by which hypoxia promotes inflammatory and autoimmune diseases. Glycolysis serves as a key metabolic checkpoint to regulate cell fate determination between Th-17 and $\mathrm{T}_{\text {reg }}$ cells. Hypoxic conditions induce a metabolic shift toward glycolysis [179], enhancing expression of HIF-1 $\alpha$ and activation, growth and proliferation of Th-1, Th-2, and Th-17 cells and also inhibit $\mathrm{T}_{\text {reg }}$ cells. Conversely, blocking glycolysis inhibits Th-17 development while promoting $\mathrm{T}_{\text {reg }}$ cell generation [152]. Under hypoxic conditions, HIF-1 $\alpha$ upregulates expression of the glucose transporters GLUT1 and GLUT3 to enhance glucose uptake and controls expression of hexokinase II, glyceraldehyde 3-phosphate dehydrogenase, lactate dehydrogenase, and mitochondrial cytochrome oxidase to increase the glycolysis rate in RA synovial tissue as well as expression of glucose phosphate isomerase; along with enolase, aldolase, and triose phosphate isomerase, glucose phosphate isomerase acts as an autoantigen [180]. Hence, in an attempt to increase energy production for cell survival, HIF- $1 \alpha$ also produces antigenic targets, thereby promoting autoimmunity. Moreover, HIF-1 $\alpha$ also invokes the differentiation of Th0 lymphocytes into Th17 cells, which are important for autoimmune disease development, including RA [181]. CD-25 expression is markedly reduced under hypoxia compared to normoxia [150], suggesting that under hypoxia, $T_{\text {reg }}$ cell activity is significantly diminished. Considering these findings, it is reasonable to hypothesize that hypoxic conditions ultimately enhance the risk for inflammatory and autoimmune diseases. 


\section{Conclusions}

In this review, we discussed all of the information reported to date on the association of smoking and hypoxic conditions with inflammatory and autoimmune diseases. The different mechanisms by which smoking and hypoxia may act as potent environmental risk factors for developing and enhancing the severity of inflammatory and autoimmune diseases were related with reference to reported studies. The different mechanisms by which smoking and hypoxic conditions induce inflammatory and autoimmune diseases, including genetic changes (somatic and germline mutations), epigenetic modifications (acetylation/deacetylation, methylation/demethylation and phosphorylation), oxidative stress, autoantibody formation, CSC heavy metal toxicity and altered immune cell proliferation and pro-inflammatory cytokine production, were analyzed separately. Studies have shown that either of these two environmental

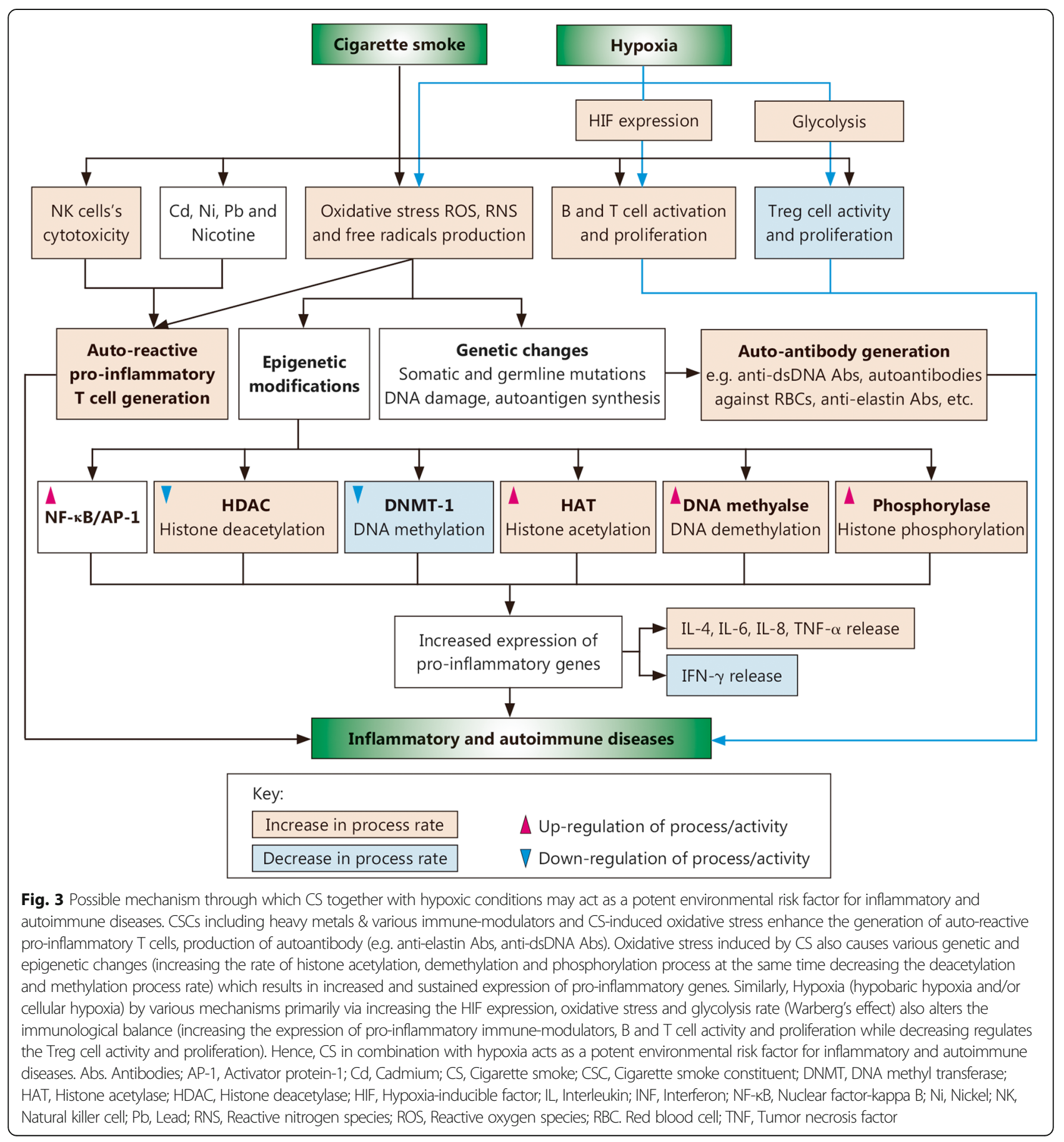


factors alone can significantly increase the risk for inflammatory and autoimmune disorders. Although studies showing a direct association of the hypoxic environment (at high altitude) with autoimmune diseases have not yet been reported, there is significant evidence to support that hypoxic conditions result in altered immune system activity, such as increased B and $\mathrm{T}$ cell proliferation, reduced $\mathrm{T}_{\text {reg }}$ cell proliferation/activity, and increased ROS production, resulting in overexpression of pro-inflammatory mediators, such as NF- $\mathrm{kB}$, IL-6, and IL-8. These data suggest that both CS and hypoxia lead to increased oxidative stress and ROS/free radical production, which in turn induces auto-reactive proinflammatory $\mathrm{T}$ cell production, autoantibody generation (e.g., anti-dsDNA, anti-elastin and anti-RBC autoantibodies), enhanced transcriptional activation/expression of pro-inflammatory mediators (e.g., IL-6, IL-4, IL-8), and reduced expression of IFN- $\gamma$ by promoting overactivation of NF- $\mathrm{KB} / \mathrm{APS}$ and various epigenetic modifications. Both CS and hypoxia can also up-regulate expression of auto-immunogenic glycolytic enzymes, reduce $\mathrm{T}_{\text {reg }}$ cell (immune-suppressive cells) activity and proliferation, and increase $\mathrm{B}$ and $\mathrm{T}$ cell activation/proliferation via a glycolytic shift (Warberg's effect), thereby increasing the release of pro-inflammatory mediators. Moreover, these effects are shared by both CS and hypoxia. CS also reduces NK cell cytotoxicity and enhances NF- $\mathrm{kB}$ activation due to the heavy metals present in CS, including $\mathrm{Cd}, \mathrm{Ni}$ and $\mathrm{Pb}$. Furthermore, smoking leverages the hypoxia induced risk of autoimmunity by inhibiting the HIF- $1 \alpha$ inhibitor- HDAC. Thus, despite some conflicting data, it is reasonable to hypothesize that smoking and hypoxia (i.e., hypobaric and cellular hypoxia) together may act as a potent environmental risk factor for inflammatory and autoimmune diseases (Fig. 3). Nonetheless, this hypothesis requires further precise studies to explore the association of highaltitude hypoxia with inflammatory and autoimmune diseases. Future studies elucidating the risk of autoimmune disease development in smokers in highaltitude regions, particularly military personnel and mountaineers not acclimatized to high-altitude stresses, may also provide a better understanding for the management of human health in high-altitude regions.

\footnotetext{
Abbreviations

AIDS: Acquired immune deficiency syndrome; AlHA: Autoimmune hemolytic anemia; AP-1: Activator protein-1; APS: Antigen presentasome; bHLH: Basic helix-loop-helix; CBP: CREB-binding protein; Cd: Cadmium; CD: Cluster of differentiation; CIA: Collagen-induced arthritis; COPD: Chronic obstructive pulmonary disease; CREB: CAMP-response element-binding protein; CS: Cigarette smoke; CSC: Cigarette smoke constituent; DNA: Deoxyribonucleic acid; DNMT: DNA methyl transferase; ERK: Extracellular signal-regulated kinase; ESTR: Expanded simple tandem repeat; FIH-1: Factor-inhibiting HIF-1; FLG: Filaggrin; FOXP3: Forkhead box P3; GD: Graves's disease; GLUT: Glucose transporter; HAT: Histone acetylase; HDAC: Histone deacetylase; HIF: Hypoxia-inducible factor; HIV: Human
}

immunodeficiency virus; HMGB-1: High-mobility group box1; HT: Hashimoto's thyroiditis; IBD: Inflammatory bowel disease; ICAM-1: Intercellular adhesion molecule-1; IgE: immunoglobulin E; IKK: IKB kinase; IL: Interleukin; INFY: Interferon gamma; IKB: Inhibitory kappa B protein; LFA (CD11a/ CD18): Lymphocyte function-associated antigen-a heterodimer composed of CD11a and CD18; MHC: Major histocompatibility complex; MMP: Matrix metalloproteinase; MS: Multiple sclerosis; MTS: Mainstream tobacco smoke; NF-kB: Nuclear factor-kappa B; Ni: Nickel; NK: Natural killer cell; NOS: Nitric oxide synthase; Nrf2: Nuclear factor erythroid 2-related factor 2;

ODD: Oxygen-dependent degradation; PA: Pernicious anemia; PAS: PerARNT-Sim; Pb: Lead; PBA: Polyclonal B cell activation; PCAF: p300/(CREBbinding protein)-associated factor; PHD: Prolyl hydroxylase; PTPRN2: Proteintyrosine phosphatase; RA: Rheumatoid arthritis; RBCs: Red blood cells; RNS: Reactive nitrogen species; RONS: Reactive oxygen and nitrogen species; ROS: Reactive oxygen species; SIRT-1: Rilent information regulator T1; SJ: Sjogren's syndrome; SLE: Rystemic lupus erythematosus; SNP: Ringlenucleotide polymorphism; STR: Rimple tandem repeats; T1D: Type-1 diabetes; TIMP-1: Tissue inhibitor of MMP1; TIP60: Tat-interactive protein 60; TNF: Tumor necrosis factor; TPO: Thyroid peroxidase; VEGF: Vascular endothelial growth factor; $\mathrm{VHL}$ : von Hippel Lindau

\section{Acknowledgments \\ Not applicable}

Funding

Not applicable

Availability of data and materials

Not applicable

\section{Authors' contributions}

The first author (MdSH) performed the literature search and drafted the manuscript; the corresponding author (VT) conceptualized, supervised and edited the manuscript. Both authors read and approved the final manuscript.

\section{Authors' information}

Md Saadam Hussain completed an M. Tech in Biotechnology from Gautam Buddha University, Greater Noida, India, and is currently pursuing a PhD. Dr. Vishwas Tripathi is an Assistant Professor, School of Biotechnology, Gautam Buddha University, Greater Noida, India.

Ethics approval and consent to participate

Not applicable

Consent for publication

Both authors have agreed to publication.

\section{Competing interests}

The authors declare that they have no competing interests.

Received: 9 July 2017 Accepted: 14 March 2018

Published online: 30 March 2018

\section{References}

1. Cooper GS, Bynum ML, Somers EC. Recent insights in the epidemiology of autoimmune diseases: improved prevalence estimates and understanding of clustering of diseases. J Autoimmun. 2009;33(3-4):197-207.

2. Lee J, Taneja V, Vassallo R. Cigarette smoking and inflammation: cellular and molecular mechanisms. J Dent Res. 2012;91(2):142-9.

3. Wipfli H. The tobacco atlas. 4th ed. New York: Oxford University Press; 2012. https://doi.org/10.1093/aje/kws389.

4. Oberg M, Jaakkola MS, Woodward A, Peruga A, Pruss-Ustun A. Worldwide burden of disease from exposure to second-hand smoke: a retrospective analysis of data from 192 countries. Lancet. 2011;377(9760):139-46.

5. Mathers CD, Loncar D. Projections of global mortality and burden of disease from 2002 to 2030. PLoS Med. 2006;3(11):e442.

6. Thun MJ, DeLancey JO, Center MM, Jemal A, Ward EM. The global burden of cancer: priorities for prevention. Carcinogenesis. 2010;31(1):100-10.

7. Ezzati M, Lopez AD. Estimates of global mortality attributable to smoking in 2000. Lancet. 2003;362(9387):847-52. 
8. Cramer T, Yamanishi Y, Clausen BE, Förster I, Pawlinski R, Mackman N, et al. HIF-1a is essential for myeloid cell-mediated inflammation. Cell. 2003;112(5):645-57.

9. Nathan C. Immunology: Oxygen and the inflammatory cell. Nature. 2003; 422(6933):675-6.

10. Taylor CT, Colgan SP. Hypoxia and gastrointestinal disease. J Mol Med. 2007; 85(12):1295-300

11. Bluhm AL, Weinstein J, Sousa JA. Free radicals in tobacco smoke. Nature. 1971;229(5285):500.

12. Ding $Y S$, Zhang $L$, Jain $R B$, Jain $N$, Wang RY, Ashley $D L$, et al. Levels of tobacco-specific nitrosamines and polycyclic aromatic hydrocarbons in main stream smoke from different tobacco varieties. Cancer Epidemiol Biomarkers Prev. 2008;17(12):3366-71.

13. Talhout R, Schulz T, Florek E, Van Benthem J, Wester P, Opperhuizen A. Hazardous compounds in tobacco smoke. Int J Environ Res Public Health. 2011:8(2):613-28.

14. IARC, World Health Organization. Tobacco smoke and involuntary smoking. larc; 2004.

15. Hoffmann D, Hoffmann I. The changing cigarette: chemical studies and bioassays. In: Burns DM, Benowitz NL, editors. Risks associated with smoking cigarettes with low machine-measured yields of tar and nicotine, vol. 13. Bethesda: US Department of Health and Human Services, Public Health Service, National Institute of Health, National Cancer Institute (NCl) Monograph; 2001. p. 159-91.

16. Swauger JE, Steichen TJ, Murphy PA, Kinsler S. An analysis of the mainstream smoke chemistry of samples of the US cigarette market acquired between 1995 and 2000. Regul Toxicol Pharmacol. 2002;35(2):142-56.

17. US Department of Health Human Services. Reducing the health consequences of smoking. 25 years of progress. A report of the Surgeon General. 1989:140-161.

18. Mehta H, Nazzal K, Sadikot RT. Cigarette smoking and innate immunity. Inflamm Res. 2008;57(11):497-503.

19. Comer DM, Elborn JS, Inflammatory EM. cytotoxic effects of acrolein, nicotine, acetylaldehyde and cigarette smoke extract on human nasal epithelial cells. BMC Pulm Med. 2014;14(1):32.

20. SCENIHR (Scientific Committee on Emerging and Newly Identified Health Risks), Addictiveness and Attractiveness of Tobacco Additives. 2010. https:// ec.europa.eu/health/scientific_committees/emerging/docs/scenihr_o_029. pdf. Accessed 15 Dec 2017.

21. Talhout R, Opperhuizen A, van Amsterdam JG. Role of acetaldehyde in tobacco smoke addiction. Eur. Neuropsychopharmacol. 2007;17(10):627-36.

22. Cao J, Belluzzi JD, Loughlin SE, Keyler DE, Pentel PR, Leslie FM. Acetaldehyde, a major constituent of tobacco smoke, enhances behavioral, endocrine, and neuronal responses to nicotine in adolescent and adult rats. Neuropsychopharmacology. 2007;32(9):2025-35.

23. Caron L, Karkazis K, Raffin TA, Koenig BA, Swan G. Nicotine addiction through a neurogenomic prism: ethics, public health, and smoking. Nicotine Tob Res. 2005;7(2):181-97.

24. Heliovaara M, Aho K, Aromaa A, Knekt P, Reunanen A. Smoking and risk of rheumatoid arthritis. J Rheumatol. 1993;20(11):1830-5.

25. Silman AJ, Newman J, Macgregor AJ. Cigarette smoking increases the risk of rheumatoid arthritis. Results from a nationwide study of disease-discordant twins. Arthritis Rheum. 1996;39(5):732-5.

26. Hutchinson D, Shepstone L, Moots R, Lear JT, Lynch MP. Heavy cigarette smoking is strongly associated with rheumatoid arthritis (RA), particularly in patients without a family history of RA. Ann Rheum Dis. 2001;60(3):223-7.

27. Vessey MP, Villard-Mackintosh L, Yeates D. Oral contraceptives, cigarette smoking and other factors in relation to arthritis. Contraception. 1987;35(5): 457-64.

28. Stolt P, Källberg H, Lundberg I, Sjögren B, Klareskog L, Alfredsson L. Silica exposure is associated with increased risk of developing rheumatoid arthritis: results from the Swedish EIRA study. Ann Rheum Dis. 2005;64(4): 582-6.

29. Karlson EW, Lee I, Cook NR, Manson JE, Buring JE, Hennekens CH. A retrospective cohort study of cigarette smoking and risk of rheumatoid arthritis in female health professionals. Arthritis Rheumatol. 1999;42(5):910-7.

30. Criswell LA, Merlino LA, Cerhan JR, Mikuls TR, Mudano AS, Burma M, et al. Cigarette smoking and the risk of rheumatoid arthritis among postmenopausal women: Results from the lowa Women's Health Study. Am J Med. 2002;112(6):465-71.

31. Uhlig T, Hagen KB, Kvien TK. Current tobacco smoking, formal education, and the risk of rheumatoid arthritis. J Rheumatol. 1999;26(1):47-54.
32. Voigt LF, Koepsell TD, Nelson JL, Dugowson CE, Daling JR. Smoking, obesity, alcohol consumption, and the risk of rheumatoid arthritis. Epidemiology. 1994;5(5):525-32.

33. Symmons DP, Bankhead CR, Harrison BJ, Brennan P, Silman AJ, Barrett EM, et al. Blood transfusion, smoking, and obesity as risk factors for the development of rheumatoid arthritis. Results from a primary care-based incident case-control study in Norfolk, England. Arthritis Rheumatol. 1997; 40(11):1955-61

34. Padyukov L, Silva C, Stolt P, Alfredsson L, Klareskog L. A gene-environment interaction between smoking and shared epitope genes in HLA-DR provides a high risk of seropositive rheumatoid arthritis. Arthritis Rheumatol. 2004:50(10):3085-92.

35. Avila MH, Liang MH, Willett WC, Stampfer MJ, Colditz GA, Rosner B, et al. Reproductive factors, smoking, and the risk for rheumatoid arthritis. Epidemiology. 1990;1 (4):285-91.

36. Hazes JM, Dijkmans BA, Vandenbroucke JP, De Vries RR, Cats A. Lifestyle and the risk of rheumatoid arthritis: cigarette smoking and alcohol consumption. Ann Rheum Dis. 1990;49(12):980-2.

37. Krishnan E, Sokka T, Hannonen P. Smoking-gender interaction and risk for rheumatoid arthritis. Arthritis Res Ther. 2003;5(3):R158.

38. Klareskog L, Stolt P, Lundberg K, Kall lberg H, Bengtsson C, Grunewald J, et al. A new model for an etiology of rheumatoid arthritis: smoking may trigger HLA-DR (shared epitope) - restricted immune reactions to auto-antigens modified by citrullination. Arthritis Rheumatol. 2006;54(1):38-46.

39. Olsson AR, Skogh T, Wingren G. Comorbidity and lifestyle, reproductive factors, and environmental exposures associated with rheumatoid arthritis. Ann Rheum Dis. 2001;60(10):934-9.

40. Costenbader KH, Feskanich D, Mandl LA, Karlson EW. Smoking intensity, duration, and cessation, and the risk of rheumatoid arthritis in women. Am J Med. 2006;119(6):e501-3. e509

41. Sugiyama D, Nishimura K, Tamaki K, Tsuji G, Nakazawa T, Morinobu A, et al. Impact of smoking as a risk factor for developing rheumatoid arthritis: a meta-analysis of observational studies. Ann Rheum Dis. 2010;69(01):70-81.

42. Freemer MM, King Jr TE, Criswell LA. Association of smoking with dsDNA autoantibody production in systemic lupus erythematosus. Ann Rheum Dis. 2006;65(5):581-4.

43. Afridi HI, Kazi TG, Talpur FN, Naher S, Brabazon D. Relationship between toxic metals exposure via cigarette smoking and rheumatoid arthritis. Clin Lab. 2014;60(10):1735-45.

44. Villard-Mackintosh L, Vessey MP. Oral contraceptives and reproductive factors in multiple sclerosis incidence. Contraception. 1993;47(2):161-8.

45. Thorogood M, Hannaford PC. The influence of oral contraceptives on the risk of multiple sclerosis. BJOG. 1998;105(12):1296-9.

46. Ghadirian P, Dadgostar B, Azani R, Maisonneuve PA. case-control study of the association between socio-demographic, lifestyle and medical history factors and multiple sclerosis. Can J Public Health. 2001;92(4):281.

47. Hernan MA, Oleky MJ, Ascherio A. Cigarette smoking and incidence of multiple sclerosis. Am J Epidemiol. 2001;154(1):69-74.

48. Riise T, Nortvedt MW, Ascherio A. Smoking is a risk factor for multiple sclerosis. Neurology. 2003;61(8):1122-4.

49. Ghaussy NO, Sibbitt WL, Qualls CR. Cigarette smoking, alcohol consumption, and the risk of systemic lupus erythematosus: a casecontrol study. J Rheumatol. 2001;28(11):2449-53.

50. Hardy CJ, Palmer BP, Muir KR, Sutton AJ, Powell RJ. Smoking history, alcohol consumption, and systemic lupus erythematosus: a case-control study. Ann Rheum Dis. 1998;57(8):451-5.

51. Nagata C, Fujita S, Iwata H, Kurosawa Y, Kobayashi K, Kobayashi M, et al. Systemic lupus erythematosus: a case-control epidemiologic study in Japan. Int J Dermatol. 1995;34(5):333-7.

52. Petri M, Thompson E, Abusuwwa R, Huang J, Garrett E. Bales: The Baltimore Lupus Environmental Study. Arthritis Rheumatol. 2001;44(9):S331.

53. Cooper GS, Dooley MA, Treadwell EL, St Clair EW, Gilkeson GS. Smoking and use of hair treatments in relation to risk of developing systemic lupus erythematosus. J Rheumatol. 2001;28(12):2653-6.

54. Reidenberg MM, Drayer DE, Lorenzo B, Strom BL, West SL, Snyder ES, et al. Acetylation phenotypes and environmental chemical exposure of people with idiopathic systemic lupus erythematosus. Arthritis Rheumatol. 1993; 36(7):971-3.

55. Benoni C, Nilsson Å, Nived O. Smoking and inflammatory bowel disease: Comparison with systemic lupus erythematosus: a case-control study. Scand J Gastroenterol. 1990;25(7):751-5. 
56. Bengtsson AA, Rylander L, Hagmar L, Nived O, Sturfelt G. Risk factors for developing systemic lupus erythematosus: a case-control study in southern Sweden. Rheumatology. 2002;41(5):563-71.

57. Sanchez-Guerrero J, Karlson EW, Colditz GA, Hunter DJ, Speizer FE, Liang $\mathrm{MH}$. Hair dye use and the risk of developing systemic lupus erythematosus: a cohort study. Arthritis Rheumatol. 1996;39(4):657-62.

58. Formica MK, Palmer JR, Rosenberg L, McAlindon TE. Smoking, alcohol consumption, and risk of systemic lupus erythematosus in the Black Women's Health Study. J Rheumatol. 2003;30(6):1222-6.

59. Vestergaard P, Rejnmark L, Weeke J, Hoeck HC, Nielsen HK, Rungby J, et al. Smoking as a risk factor for Graves' disease, toxic nodular goiter, and autoimmune hypothyroidism. Thyroid. 2002;12(1):69-75.

60. Chen YL, Chang TC, Chen CJ. Influence of smoking on Graves' disease with or without ophthalmopathy and nontoxic nodular goiter in Taiwan. J Formos Med Assoc. 1994;93(1):40-4

61. Winsa B, Mandahl A, Karlsson FA. Graves' disease, endocrine ophthalmopathy and smoking. Acta Endocrinol. 1993;128(2):156-60.

62. Yoshiuchi K, Kumano H, Nomura S, Yoshimura H, Ito K, Kanaji Y, et al. Stressful life events and smoking were associated with Graves' disease in women, but not in men. Psychosom Med. 1998;60(2):182-5.

63. Brix TH, Hansen PS, Kyvik KO, Hegedüs L. Cigarette smoking and risk of clinically overt thyroid disease: a population-based twin case-control study. Arch Intern Med. 2000;160(5):661-6.

64. Bartalena L, Martino E, Marcocci C, Bogazzi F, Panicucci M, Velluzzi F, et al. More on smoking habits and Graves' ophthalmopathy. J Endocrinol Invest. 1989;12(10):733-7

65. Pfeilschifter J, Ziegler R. Smoking and endocrine ophthalmopathy: impact of smoking severity and current vs lifetime cigarette consumption. Clin Endocrinol. 1996;45(4):477-81.

66. Holm IA, Manson JE, Michels KB, Alexander EK, Willett WC, Utiger RD. Smoking and other lifestyle factors and the risk of Graves' hyperthyroidism. Arch Intern Med. 2005;165(14):1606-11.

67. Howel D, Fischbacher CM, Bhopal RS, Gray J, Metcalf JV, James OF. An exploratory population-based case-control study of primary biliary cirrhosis. Hepatology. 2000;31(5):1055-60.

68. Gershwin ME, Selmi C, Worman HJ, Gold EB, Watnik M, Utts J, et al. Risk factors and comorbidities in primary biliary cirrhosis: a controlled interviewbased study of 1032 patients. Hepatology. 2005;42(5):1194-202.

69. Ross KA. Evidence for somatic gene conversion and deletion in bipolar disorder, Crohn's disease, coronary artery disease, hypertension, rheumatoid arthritis, type-1 diabetes, and type-2 diabetes. BMC Med. 2011;9(1):12.

70. Bois PR. Hyper mutable minisatellites, a human affair? Genomics. 2003;81(4): 349-55.

71. Ellegren H. Microsatellites: simple sequences with complex evolution. Nature Rev Genet. 2004;5(6):435.

72. Holmes R, Chang Y, Soloway PD. Timing and sequence requirements defined for embryonic maintenance of imprinted DNA methylation at Rasgrf1. Mol Cell Biol. 2006;26(24):9564-70

73. Yauk CL, Polyzos A, Rowan-Carroll A, Kortubash I, Williams A, Kovalchuk O. Tandem repeat mutation, global DNA methylation, and regulation of DNA methyltransferases in cultured mouse embryonic fibroblast cells chronically exposed to chemicals with different modes of action. Environ Mol Mutagen. 2008:49(1):26-35.

74. Shukla S, Kavak E, Gregory M, Imashimizu M, Shutinoski B, Kashlev M, et al. CTCF-promoted RNA polymerase II pausing links DNA methylation to splicing. Nature. 2011;479(7371):74.

75. Renaudineau Y, Youinou P. Epigenetics and autoimmunity, with special emphasis on methylation. Keio J Med. 2011;60(1):10-6.

76. Ross KA. Coherent somatic mutation in autoimmune disease. PloS one. 2014;9(7):e101093.

77. Fiorillo E, Orrú V, Stanford SM, Liu Y, Salek M, Rapini N, et al. Autoimmuneassociated PTPN22 R620W variation reduces phosphorylation of lymphoid phosphatase on an inhibitory tyrosine residue. J Biol Chem. 2010;285(34): 26506-18.

78. Criswell LA, Pfeiffer KA, Lum RF, Gonzales B, Novitzke J, Kern M, et al. Analysis of families in the multiple autoimmune disease genetics consortium (MADGC) collection: the PTPN22 620W allele associates with multiple autoimmune phenotypes. Am J Hum Genet. 2005;76(4):561-71.

79. Menard L, Saadoun D, Isnardi I, Ng YS, Meyers G, Massad C, et al. The PTPN22 allele encoding an R620W variant interferes with the removal of developing autoreactive B cells in humans. J Clin Invest. 2011;121(9):3635.
80. Arechiga AF, Habib T, He Y, Zhang X, Zhang ZY, Funk A, et al. Cutting edge: the PTPN22 allelic variant associated with autoimmunity impairs B cell signaling. J Immunol. 2009;182(6):3343-7.

81. Zhang J, Zahir N, Jiang Q, Miliotis H, Heyraud S, Meng X, et al. The autoimmune disease-associated PTPN22 variant promotes calpain-mediated Lyp/Pep degradation associated with lymphocyte and dendritic cell hyperresponsiveness. Nature Genet. 2011;43(9):902-7.

82. DeMarini DM. Genotoxicity of tobacco smoke and tobacco smoke condensate: a review. Mutat Res Rev Mutat Res. 2004;567(2):447-74.

83. Roemer E, Schramke H, Weiler H, Buettner A, Kausche S, Weber S, et al. Mainstream smoke chemistry and in vitro and in vivo toxicity of the reference cigarettes 3R4F and 2R4F. Beitragezur Tab Int Contrib Tob Res. 2012;25(1):316-35

84. Pryor WA, Stone K, Zang LY, Bermúdez E. Fractionation of aqueous cigarette tar extracts: fractions that contain the tar radical cause DNA damage. Chem Res Toxicol. 1998;11(5):441-8.

85. DeMarini DM. Genotoxicity of tobacco smoke and tobacco smoke condensate. Mutat Res Rev Genet Toxicol. 1983;114(1):59-89.

86. International Agency for Research on Cancer. Tobacco smoking (IARC Monographs on the Evaluation of the Carcinogenic Risk of Chemicals to Humans, Vol. 38). Lyon: International Agency for Research on Cancer (IARC Press); 1986.

87. Husgafvel-Pursiainen K. Genotoxicity of environmental tobacco smoke: a review. Mutat Res Rev Mutat Res. 2004;567(2):427-45.

88. Podlutsky A, Hou SM, Nyberg F, Pershagen G, Lambert B. Influence of smoking and donor age on the spectrum of in vivo mutation at the HPRTlocus in T lymphocytes of healthy adults. Mutat Res Fund Mol Mech Mut. 1999:431(2):325-39.

89. Keohavong P, Xi L, Day RD, Zhang L, Grant SG, Day BW, et al. HPRT gene alterations in umbilical cord blood T-lymphocytes in newborns of mothers exposed to tobacco smoke during pregnancy. Mutat Res Fund Mol Mech Mut. 2005;572(1):156-66

90. Mahdi H, Fisher BA, Källberg H, Plant D, Malmström V, Rönnelid J, et al. Specific interaction between genotype, smoking and autoimmunity to citrullinated a-enolase in the etiology of rheumatoid arthritis. Nat Genet 2009;41(12):1319-24

91. van der Woude D, Alemayehu WG, Verduijn W, de Vries RR, HouwingDuistermaat JJ, Huizinga TW, et al. Gene-environment interaction influences the reactivity of autoantibodies to citrullinated antigens in rheumatoid arthritis. Nat Genet. 2010;42(10):814-6.

92. Robbins WA, Elashoff DA, Xun L, Jia J, Li N, Wu G, et al. Effect of lifestyle exposures on sperm aneuploidy. Cytogenet Genome Res. 2005;111(3-4):371-7.

93. Yauk CL, Berndt ML, Williams A, Rowan-Carroll A, Douglas GR, Stämpfli MR. Mainstream tobacco smoke causes paternal germ-line DNA mutation. Cancer Res. 2007:67(11):5103-6.

94. Hruba D, Sikolova V, Kunzova S, Kasikova K. The role of smoking in the epigenetic modification of phenotype: the latest knowledge about smoking-induced pathways. Cas Lek Cesk. 2013;152(1):31-5.

95. Rajendrasozhan S, Yao H, Rahman I. Current perspectives on role of chromatin modifications and deacetylases in lung inflammation of COPD. COPD. 2009;6(4):291-7

96. Lengfeld J, Cutforth T, Agalliu D. The role of angiogenesis in the pathology of multiple sclerosis. Vascular Cell. 2014;6(1):23.

97. Sternglanz R. Histone acetylation: a gateway to transcriptional activation. Trends Biochem Sci. 1996;21(10):357-8.

98. Brown CE, Lechner T, Howe LE, Workman JL. The many HATs of transcription coactivators. Trends Biochem Sci. 2000;25(1):15-9.

99. Wu C. Chromatin remodeling and the control of gene expression. J Biol Chem. 1997;272:28171-4

100. deRuijter AJ, van Gennip AH, Caron HN, Kemp S, van Kuilenburg AB. Histone deacetylases (HDACs):characterization of the classical HDAC family. Biochem J. 2003;370(3):737-49.

101. Yang XJ, Gregoire S. Class II histone deacetylases:fromsequence to function, regulation, and clinicalimplication. Mol Cell Biol. 2005;25(8):2873-84.

102. Yang XJ, Seto E. The Rpd3/Hda1 family of lysine deacetylases: from bacteria and yeast to mice and men. Nat Rev Mol Cell Biol. 2008;9(3):206-18.

103. Wang Z, Zang C, Cui K, Schones DE, Barski A, Peng W, et al. Genome-wide mapping of HATs and HDACs reveals distinct functions in active and inactive genes. Cell. 2009;138(5):1019-31.

104. Haery L, Thompson RC, Gilmore TD. Histone acetyl transferases and histone deacetylases in B-and T-cell development, physiology and malignancy. Genes Cancer. 2015;6(5-6):184-213. 
105. Sun XJ, Man N, Tan Y, Nimer SD, Wang L. The role of histone acetyl transferases in normal and malignant hematopoiesis. Front Oncol. 2015;5(108):1-11.

106. Moodie FM, Marwick JA, Anderson CS, Szulakowski P, Biswas SK, Bauter MR, et al. Oxidative stress and cigarette smoke alter chromatin remodeling but differentially regulate NF-KB activation and proinflammatory cytokine release in alveolar epithelial cells. FASEB J. 2004;18(15):1897-9.

107. Rajendrasozhan S, Yang SR, Caito S, Rahman I. Nucleocytoplasmic shuttling and posttranslational modifications of sirtuin in response to cigarette smoke lead to increased acetylation of NF-KB and FOXO3. Am J Respir Crit Care Med. 2008;177:A266.

108. Somers EC, Richardson BC. Environmental exposures, epigenetic changes and the risk of lupus. Lupus. 2014;23(6):568-76.

109. Walters MJ, Paul-Clark MJ, McMaster SK, Ito K, Adcock IM, Mitchell JA. Cigarette smoke activates human monocytes by an oxidant- AP-1 signaling pathway: implications for steroid resistance. Mol Pharmacol. 2005;68(5):1343-53.

110. Yang SR, Chida AS, Bauter MR, Shafiq N, Seweryniak K, Maggirwar SB, et al. Cigarette smoke induces pro-inflammatory cytokine release by activation of NF-kappaB and posttranslational modifications of histone deacetylase in macrophages. Am J Physiol Lung Cell Mol Physiol. 2006;291(11):L46-57.

111. Adenuga D, Yao H, March TH, Seagrave J, Rahman I. Histone deacetylase 2 is phosphorylated, ubiquitinated and degraded by cigarette smoke. Am J Respir Cell Mol Biol. 2009;40(4):464-73.

112. Yao H, Edirisinghe I, Rajendrasozhan S, Yang SR, Caito S, Adenuga D, et al. Cigarette smoke mediated inflammatory and oxidative responses are straindependent in mice. Am J Physiol Lung Cell Mol Physiol. 2008;294(6):L1174-86.

113. Yao H, Yang SR, Kode A, Rajendrasozhan S, Caito S, Adenuga D, et al. Redox regulation of lung inflammation: role of NADPH oxidase and NF-kappaB signalling. Biochem Soc Trans. 2007;35(5):1151-5.

114. Ito K, Barnes PJ, Adcock IM. Glucocorticoid receptor recruitment of histone deacetylase 2 inhibits interleukin-1beta-induced histone $\mathrm{H} 4$ acetylation on lysines 8 and 12. Mol Cell Biol. 2000;20(18):6891-903.

115. Mercado N, Thimmulappa R, Thomas CMR, Fenwick PS, Chana KK, Donnelly $L E$, et al. Decreased histone deacetylase 2 impairs Nrf2 activation by oxidative stress. Biochem Biophys Res Commun. 2011;406(2):292-8.

116. Li YP, Gorelik G, Strickland FM, Richardson BC. Oxidative Stress, T Cell DNA Methylation, and Lupus. Arthritis Rheumatol. 2014;66(6):1574-82.

117. Fujii J, Kurahashi T, Konno T, Homma T, luchi Y. Oxidative stress as a potential causal factor for autoimmune hemolytic anemia and systemic lupus erythematosus. World J Nephrol. 2015;4(2):213-22.

118. Yang SR, Valvo S, Yao H, Kode A, Rajendrasozhan S, Edirisinghe I, et al. IKK alpha causes chromatin modification on pro-inflammatory genes by cigarette smoke in mouse lung. Am J Respir Cell Mol Biol. 2008;38(6):689-98.

119. Lunec J, Herbert K, Blount S, Griffiths HR, Emery P. 8-Hydroxy deoxyguanosine: a marker of oxidative DNA damage in systemic lupus erythematosus. FEBS Lett. 1994;348(2):131-8.

120. Ohsawa M. Heavy metal induced immunotoxicity and its mechanisms. Yakugaku Zasshi. 2009;129(3):305-19.

121. Tsai CP, Lee CT. Multiple sclerosis incidence associated with the soil lead and arsenic concentrations in Taiwan. PLoS One. 2013;8(6):e65911.

122. Freitas M, Fernandes E. Zinc, cadmium and nickel increase the activation of NF-KB and the release of cytokines from THP-1 monocytic cells. Metallomics. 2011;3(11):1238-43.

123. Vassallo R, Tamada K, Lau JS, Kroening PR, Chen L. Cigarette smoke extract suppresses human dendritic cell function leading to preferential induction of Th-2 priming. J Immunol. 2005;175(4):2684-91.

124. Robays L, Lanckacker EA, Moerloose KB, Maes T, Bracke KR, Brusselle GG, et al. Concomitant inhalation of cigarette smoke andaerosolized protein activates airway dendritic cells and induces allergic airwayinflam-mationin a TLR-independent way. J Immunol. 2009;183(4):2758-66.

125. Lee SH, Goswami S, Grudo A, Song LZ, Bandi V, Goodnight-White S, et al. Antielastin autoimmunity in tobacco smoking-induced emphysema. Nat Med. 2007;13(5):567-9.

126. Mian MF, Lauzon NM, Stampfli MR, Mossman KL, Ashkar AA. Impairment of human NK cell cytotoxic activity and cytokine release by cigarette smoke. J Leukoc Biol. 2008;83(3):774-84.

127. Smeltz RB, Wolf NA, Swanborg RH. Inhibition of autoimmune T cell responses in the DA Rat by bone marrow-derived NK cells in vitro: Implications for autoimmunity. J Immunol. 1999;163(3):1390-7.

128. Prummel MF, Strieder T, Wiersinga WM. The environment and autoimmune thyroid diseases. Eur J Endocrinol. 2004;150(5):605-18.

129. Zhou L, Chong MM, Littman DR. Plasticity of CD4 ${ }^{+} \mathrm{T}$ cell lineage differentiation. Immunity. 2009;30(5):646-55.
130. Byron KA, Varigos GA, Wootton AM. IL-4 production is increased in cigarette smokers. Clin Exp Immunol. 1994;95(2):333-6.

131. Nakamura Y, Miyata M, Ohba T, Ando T, Hatsushika K, Suenaga F, et al. Cigarette smoke extract induces thymic stromal lymphopoietin expression, leading to $T(H)$ 2-type immune responses and airway inflammation. J Allergy Clin Immunol. 2008;122(6):1208-14.

132. Van Hove CL, Moerloose K, Maes T, Joos GF, Tournoy KG. Cigarette smoke enhances Th-2 driven airway inflammation and delays inhalational tolerance. Respir Res. 2008;9(1):42.

133. deHeens GL, van der Velden U, Loos BG. Cigarette smoking enhances T cell activation and a Th2 immune response; an aspect of the pathophysiology in periodontal disease. Cytokine. 2009;47(3):157-61.

134. Smelter DF, Sathish V, Thompson MA, Pabelick CM, Vassallo R, Prakash YS. Thymic stromal lymphopoietin in cigarette smoke-exposed human airway smooth muscle. J Immunol. 2010;185(5):3035-40.

135. Shan M, Cheng HF, Song LZ, Roberts L, Green L, Hacken-Bitar J, et al. Lung myeloid dendritic cells coordinately induce $\mathrm{TH} 1$ and $\mathrm{TH} 17$ responses in human emphysema. Sci Transl Med. 2009;1(4):4ra10.

136. Zivadinov R, Weinstock-Guttman B, Hashmi K, Abdelrahman N, Stosic M, Dwyer $\mathrm{M}$, et al. Smoking is associated with increased lesion volumes and brain atrophy in multiple sclerosis. Neurology. 2009;73(7):504-10.

137. Bakonyi T, Radák Z. High altitude and free radicals. J Sports Sci Med. 2004; 3(2):64-9.

138. Dosek A, Ohno H, Acs Z, Taylor AW, Radak Z. High altitude and oxidative stress. Respir Physiol Neurobiol. 2007;158(2):128-31.

139. Karakucuk S. Effects of High Altitude Related Oxidative Stress on Intraocular Pressure and Central Corneal Thickness-A Research Model for the Etiology of Glaucoma. In: Rumelt S, editor. Glaucoma-Basic and Clinical Concepts. Europe: In Tech; 2011. p. 271-90.

140. Jefferson JA, Simoni J, Escudero E, Hurtado ME, Swenson ER, Wesson DE, et al. Increased oxidative stress following acute and chronic high altitude exposure. High Alt Med Biol. 2004;5(1):61-9.

141. Semenza GL, Wang GL. A nuclear factor induced by hypoxia via de novo protein synthesis binds to the human erythropoietin gene enhancer at a site required for transcriptional activation. Mol Cell Biol. 1992;12(12):5447-54.

142. Patel SA, Simon MC. Biology of hypoxia-inducible factor-2alpha in development and disease. Cell Death Differ. 2008;15(4):628-34.

143. Huh YH, Lee G, Lee KB, Koh JT, Chun JS, Ryu JH. HIF-2a-induced chemokines stimulate motility of fibroblast-like synoviocytes and chondrocytes into the cartilage-pannus interface in experimental rheumatoid arthritis mouse models. Arthritis Res Ther. 2015;17(1):302.

144. Pan F, Barbi J, Pardoll DM. Hypoxia-inducible factor1: a link between metabolism and $\mathrm{T}$ cell differentiation and a potential therapeutic target. Oncoimmunology. 2012;1(4):510-5.

145. Biddlestone J, Bandarra D, Rocha S. The role of hypoxia in inflammatory disease. Int J Mol Med. 2015;35(4):859-69.

146. Kaelin WG, Ratcliffe PJ. Oxygen sensing by metazoans: the central role of the HIF hydroxylase pathway. Mol Cell. 2008;30(4):393-402.

147. Mahon PC, Hirota K, Semenza GL. FIH-1: a novel protein that interacts with HIF-1alpha and VHL to mediate repression of HIF-1 transcriptional activity. Genes Dev. 2001;15(20):2675-86.

148. Lando D, Peet DJ, Gorman JJ, Whelan DA, Whitelaw ML, Bruick RK. FIH-1 is an asparaginyl hydroxylase enzyme that regulates the transcriptional activity of hypoxia-inducible factor. Genes Dev. 2002;16(12):1466-71.

149. Lando D, Peet DJ, Whelan DA, Gorman JJ, Whitelaw ML. Asparagine hydroxylation of the HIF transactivation domain a hypoxic switch. Science. 2002;295(5556):858-61.

150. Bollinger T, Gies S, Naujoks J, Feldhoff L, Bollinger A, Solbach W, et al. HIF1a-and hypoxia-dependent immune responses in human CD4+CD25 high Tcells and T helper 17cells. J Leukoc Biol. 2014;96(2):305-12.

151. Hu F, Shi L, Mu R, Zhu J, Li Y, Ma X, et al. Hypoxia-inducible factor-1a and interleukin 33 form a regulatory circuit to perpetuate the inflammation in rheumatoid arthritis. PLoS One. 2013;8(8):e72650

152. Shi LZ, Wang R, Huang G, Vogel P, Neale G, Green DR, et al. HIF1adependent glycolytic pathway orchestrates a metabolic checkpoint for the differentiation of $T_{H} 17$ and $T_{\text {reg }}$ cells. J Exp Med. 2011;208(7):1367-76.

153. Geng H, Harvey CT, Pittsenbarger J, Liu Q, Beer TM, Xue C, et al. HDAC4 Protein regulates HIF1a protein lysine acetylation and cancer cell response to hypoxia. J Biol Chem. 2011;286(44):38095-102.

154. Maltzman JS, Haase VH. Low oxygen stimulates the immune system. Kidney Int. 2008;73(7):797-9. 
155. Imig JD, Ryan MJ. Immune and inflammatory role in renal disease. Compr Physiol. 2013;3(2):957-76

156. Cummins EP, Taylor CT. Hypoxia-responsive transcription factors. Pflugers Arch. 2005;450(6):363-71.

157. Koong AC, Chen EY, Giaccia AJ. Hypoxia causes the activation of nuclear factor $k B$ through the phosphorylation of $1 k B a$ on tyrosine residues. Cancer Res. 1994;54(6):1425-30.

158. Simmonds RE, Foxwell BM. Signalling, inflammation and arthritis: NF-kappa $B$ and its relevance to arthritis and inflammation. Rheumatol Oxf Engl. 2008; 47(5):584-90.

159. Benito MJ, Murphy E, Murphy EP, vanden Berg WB, Fitz Gerald O, Bresnihan B. Increased synovial tissue NF-kappa B1 expression at sites adjacent to the cartilage-pannus junction in rheumatoid arthritis. Arthritis Rheum. 2004; 50(6):1781-7.

160. Handel ML, McMorrow LB, Gravallese EM. Nuclear factor- kappa B in rheumatoid synovium. Localization of p50 and p65. Arthritis Rheum. 1995; 38(12):1762-70.

161. Müller-Ladner U, Pap T, Gay RE, Neidhart M, Gay S. Mechanisms of disease: The molecular and cellular basis of joint destruction in rheumatoid arthritis. Nat Clin Pract Rheumatol. 2005;1(2):102-10.

162. Aggarwal BB, Takada Y, Shishodia S, Gutierrez AM, Oommen OV, Ichikawa H, et al. Nuclear transcription factor NF-kappa B: role in biology and medicine. Indian J Exp Biol. 2004:42(4):341-53.

163. Lund-Olesen K. Oxygen tension in synovial fluids. Arthritis Rheum. 1970; 13(6):769-76.

164. Falchuk KH, Goetzl EJ, Kulka JP. Respiratory gases of synovial fluids. An approach to synovial tissue circulatory-metabolic imbalance in rheumatoid arthritis. Am J Med. 1970;49(2):223-31.

165. Sivakumar B, Akhavani MA, Winlove CP, Taylor PC, Paleolog EM, Kang N. Synovial hypoxia as a cause of tendon rupture in rheumatoid arthritis. $J$ Hand Surg. 2008;33(1):49-58.

166. Ng CT, Biniecka M, Kennedy A, McCormick J, Fitzgerald O, Bresnihan B, et al. Synovial tissue hypoxia and inflammation in vivo. Ann Rheum Dis. 2010; 69(7):1389-95.

167. Jeon CH, Ahn J-K, Chai J-Y, Kim HJ, Bae E-K, Park SH, et al. Hypoxia appears at pre-arthritic stage and shows co-localization with early synovial inflammation in collagen induced arthritis. Clin Exp Rheumatol. 2008;26(4): 646-8.

168. Quinonez-Flores CM, Gonzalez-Chayez SA, Pacheco-Tena C. Hypoxia and its implications in rheumatoid arthritis. J Biomed sci. 2016;23(1):62.

169. Li G, Zhang Y, Qian Y, Zhang H, Guo S, Sunagawa M, et al. Interleukin-17A promotes rheumatoid arthritis synoviocytes migration and invasion under hypoxia by increasing MMP2 and MMP9 expression through NF-kB/HIF-1a pathway. Mol Immunol. 2013;53(3):227-36.

170. Ahn JK, Koh E-M, Cha H-S, Lee YS, Kim J, Bae EK, et al. Role of hypoxiainducible factor-1alpha in hypoxia-induced expressions of IL-8, MMP-1 and MMP-3 in rheumatoid fibroblast-like synoviocytes. Rheumatol Oxf Engl. 2008;47(6):834-9.

171. Cha HS, Ahn KS, Jeon CH, Kim J, Song YW, Koh EM. Influence of hypoxia on the expression of matrix metalloproteinase-1, -3 and tissue inhibitor of metalloproteinase-1 in rheumatoid synovial fibroblasts. Clin Exp Rheumatol. 2003;21(5):593-8.

172. Oikawa M, Abe M, Kurosawa H, Hida W, Shirato K, Sato Y. Hypoxia induces transcription factor ETS-1 via the activity of hypoxia-inducible factor-1. Biochem Biophys Res Commun. 2001;289(1):39-43.

173. Behrens P, Mathiak M, Mangold E, Kirdorf S, Wellmann A, Fogt F, et al. Stromal expression of invasion-promoting, matrix-degrading proteases MMP-1 and -9 and the Ets 1 transcription factor in HNPCC carcinomas and sporadic colorectal cancers. Int J Cancer. 2003;107(2):183-8.

174. Belaiba RS, Bonello S, Zähringer C, Schmidt S, Hess J, Kietzmann T, et al. Hypoxia up-regulates hypoxia-inducible factor-1 $a$ transcription by involving phosphatidyl inositol 3-kinase and nuclear factor $k B$ in pulmonary artery smooth muscle cells. Mol Biol Cell. 2007;18(12):4691-7.

175. Rius J, Guma M, Schachtrup C, Akassoglou K, Zinkernagel AS, Nizet V, et al. $\mathrm{NF}-\mathrm{KB}$ links innate immunity to the hypoxic response through transcriptional regulation of HIF-1a. Nature. 2008:453(7196):807-11.

176. Van Uden P, Kenneth NS, Rocha S. Regulation of hypoxia-inducible factor-1a by NF-KB. Biochem J. 2008;412(3):477-84.

177. Scortegagna M, Cataisson C, Martin RJ, Hicklin DJ, Schreiber RD, Yuspa SH, et al. HIF-1a regulates epithelial inflammation by cell autonomous NFkB activation and paracrine stromal remodeling. Blood. 2008;111(7):3343-54.
178. Karhausen J, Furuta GT, Tomaszewski JE, Johnson RS, Colgan SP, Haase VH. Epithelial hypoxia-inducible factor-1 is protective in murine experimental colitis. J Clin Invest. 2004;114(8):1098-106.

179. Donohoe DR, Collins LB, Wali A, Bigler R, Sun W, Bultman SJ. The Warburg effect dictates the mechanism of butyrate-mediated histone acetylation and cell proliferation. Mol Cell. 2012;48(4):612-26.

180. Chang X, Wei C. Glycolysis and rheumatoid arthritis. Int J Rheum Dis. 2011; 14(3):217-22.

181. Dang EV, Barbi J, Yang H-Y, Jinasena D, Yu H, Zheng Y, et al. Control of $T(H) 17 /$ $\mathrm{T}$ (reg) balance by hypoxia-inducible factor 1. Cell. 2011;146(5):772-84.

\section{Submit your next manuscript to BioMed Central and we will help you at every step:}

- We accept pre-submission inquiries

- Our selector tool helps you to find the most relevant journal

- We provide round the clock customer support

- Convenient online submission

- Thorough peer review

- Inclusion in PubMed and all major indexing services

- Maximum visibility for your research

Submit your manuscript at www.biomedcentral.com/submit
Biomed Central 